\title{
Development and surveillance of hepatocellular carcinoma in patients with sustained virologic response after antiviral therapy for chronic hepatitis C
}

\author{
Seong Kyun $\mathrm{Na}$ and Byung-Cheol Song \\ Department of Internal Medicine, Jeju National University School of Medicine, Jeju, Korea
}

\begin{abstract}
Hepatitis C virus (HCV) infection is a major risk factor for liver cirrhosis and hepatocellular carcinoma (HCC), and is a leading cause of liver-related deaths worldwide. Recently available direct-acting antiviral agent is very safe and highly effective ( $>95 \%$ sustained virologic response, SVR) against all genotypes of HCV. Achievement of SVR has been associated with a significant reduction of hepatic decompensation, development of HCC, and liver-related mortality. However, HCC risk is not eliminated even after SVR. The annual incidences of HCC in advanced fibrosis or cirrhosis have been estimated to be up to $2.5-4.5 \%$ even in patients with SVR. Therefore, surveillance for HCC is recommended in this high-risk patients. In this review, we will describe the clinical outcomes and the risk of HCC in patients with SVR and suggest who should receive surveillance for HCC. (Clin Mol Hepatol 2019;25:234-244)
\end{abstract}

Keywords: Chronic hepatitis C; Sustained virologic response; Hepatocellular carcinoma

\section{INTRODUCTION}

Hepatitis C virus (HCV) infection is a major risk factor for liver cirrhosis and hepatocellular carcinoma (HCC), and is a leading cause of liver-related deaths worldwide. It is estimated that approximately $130-170$ million individuals $(2.3 \%$ of the world population) are chronically infected with HCV. If the patients were not treated, $10-20 \%$ of whom will progress to liver cirrhosis over 20-30 years of infection and HCC develops in $1-5 \%$ of patients with liver cirrhosis each year.

In patients with chronic hepatitis $\mathrm{C}(\mathrm{CHC})$, achievement of a sustained virologic response (SVR) by interferon (IFN) treatment has been associated with a significant reduction of hepatic de- compensation, development of HCC, and liver-related mortality. ${ }^{2,3}$ Previous studies have shown that hepatic decompensation rarely occurred in patients with SVR (annual incidence <0.1\%). In patients with advanced liver fibrosis or cirrhosis, however, even after achieving SVR after IFN treatment, the annual incidence of HCC is reported to be as high as $2.5-4.5 \%$. ${ }^{4,5}$

Recently available direct-acting antiviral agent (DAA) is very safe and highly effective (>95\% SVR) against all genotypes of $\mathrm{HCV}$. They are applicable to all patients with HCV, including old age, those with decompensated liver disease and end stage renal disease who are unfit to IFN therapy. ${ }^{6-10}$ In the era of highly effective and safe DAA for the treatment of $\mathrm{CHC}$ patients, identifying high-risk groups of HCC and monitoring them continuously is an

\section{Abbreviations:}

$\mathrm{CHC}$, chronic hepatitis $\mathrm{C}$; DAA, direct-acting antiviral agent; $\mathrm{HCC}$, hepatocellular carcinoma; $\mathrm{HCV}$, hepatitis $\mathrm{C}$ virus; IFN, interferon; SVR, sustained virologic response
Corresponding author : Byung-Cheol Song

Department of Internal Medicine, Jeju National University School of Medicine, 15 Aran 13-gil, Jeju 63241, Korea

Tel: +82-64-754-8177, Fax: +82-64-717-1121

E-mail: drsong8177@naver.com

https://orcid.org/0000-0002-8319-3375 
important clinical issue.

In this review, we will describe the clinical outcomes and the risk of HCC in patients with SVR and suggest who should receive surveillance for HCC.

\section{OUTCOMES OF PATIENTS WITH SVR AFTER IFN-BASED THERAPY}

Of the studies that included patients with all stages of fibrosis (Table 1), many studies reported in Japan, Yoshida et al. ${ }^{11}$ reported a retrospective analysis of 2,890 patients (2,400 received IFN and 490 untreated) with biopsy-proven CHC. During a mean followup of 4.3 years, HCC developed in 89 IFN-treated patients (including 10 patients in SVR) and in 59 untreated patients. The annual incidence of HCC increased with the degree of liver fibrosis in untreated, non SVR and SVR patients ( 0.45 vs. 0.07 vs. $0.11 \%$ in $\leq \mathrm{F} 1$,
1.99 vs. 0.78 vs. $0.1 \%$ in $F 2$ and 5.34 vs. 2.2 vs.1.29\% in F3 and 7.88 vs. 5.32 vs. $0.49 \%$ in F4, respectively). In Taiwan, a total of 1,619 patients with biopsy-proven $\mathrm{CHC}$, including 1,057 patients receiving IFN-based therapy and 562 untreated controls were enrolled in retrospective-prospective cohort study and followed for 5.18 years after treatment. ${ }^{5}$ The cumulative incidence of HCC was significantly lower in patients with SVR (3.0\%) than in those without SVR (36.0\%, $P=0.007)$ and untreated patients (35.2\%) $(P<0.0001)$. The annual incidence of HCC after SVR was higher in cirrhotic patients compared with non-cirrhotic patients (2.7\% vs. $0.09 \%) .^{5}$ In a prospective study of 642 SVR patients, ${ }^{4}$ conducted in Taiwan, 33 of the 642 (5.1\%) patients developed HCC during median follow-up of 53 months. The annual incidences of HCC were higher in patients with liver cirrhosis compared with non-cirrhotic patients (4.54\% vs. $0.14-2.80 \%$ depending on additional risk factors). The above results were confirmed in Western countries. $^{12,13}$ In a recent large-scale study ${ }^{13}$ conducted in Canada,

Table 1. Summary of studies reporting annual incidence of hepatocellular carcinoma in all stages of fibrosis patients receiving interferon-based therapy

\begin{tabular}{|c|c|c|c|c|c|c|c|}
\hline Study & Response & $\begin{array}{l}\text { Patients } \\
\text { No. }\end{array}$ & $\begin{array}{l}\text { Male } \\
(\%)\end{array}$ & Age (years) & $\begin{array}{l}\text { Fibrosis (\%) } \\
\text { (F1/F2/F3/F4) }\end{array}$ & $\begin{array}{l}\text { Follow-up } \\
\text { (years) }\end{array}$ & $\begin{array}{c}\text { Annual incidence (\%) } \\
\text { (F1/F2/F3/F4) }\end{array}$ \\
\hline \multicolumn{8}{|l|}{$\begin{array}{l}\text { Studies that included patients } \\
\text { with all stage of fibrosis }\end{array}$} \\
\hline \multirow[t]{3}{*}{ Yoshida et al.", Japan, RS } & No Tx. & 490 & 55.1 & $53.6 \pm 11.2$ & $32.6 / 33.5 / 12.0 / 21.8$ & 4.3 & $0.45 / 1.99 / 5.34 / 7.88$ \\
\hline & $\operatorname{SVR}(-)$ & 1,568 & 63.8 & $49.5 \pm 11.3$ & 29.6/37.3/23.5/9.6 & & $0.07 / 0.78 / 2.2 / 5.32$ \\
\hline & $\operatorname{SVR}(+)$ & 789 & & & & & $0.11 / 0.1 / 1.29 / 0.49$ \\
\hline \multirow[t]{3}{*}{ Yoshida et al. ${ }^{30}$, Japan, RS } & No Tx. & 395 & 51.6 & $55.0 \pm 10.7$ & $32.4 / 35.7 / 10.6 / 21.2$ & $6.5 \pm 2.8$ & \\
\hline & $\operatorname{SVR}(-)$ & 1,556 & 63.7 & $50.5 \pm 6.4$ & $30 / 37.6 / 23.2 / 9.2$ & $7.4 \pm 2.9$ & $2.5(4.8: F 3+F 4)$ \\
\hline & $\operatorname{SVR}(+)$ & 836 & & $47.7 \pm 11.9$ & & $6.7 \pm 3.0$ & $0.6(1.3: F 3+F 4)$ \\
\hline Ikeda et al. ${ }^{31}$, Japan, RS & SVR (+) & 1,056 & 67 & $50(11-76)$ & $40.8 / 28.5 / 16.1 / 9.2$ & 4.7 & $\begin{array}{c}0.56 \\
(0.27 / 0.47 / 0.62 / 1.31)\end{array}$ \\
\hline \multirow[t]{3}{*}{ Yu et al. ${ }^{5}$, Taiwan, RS/PS } & No Tx. & 562 & 61.7 & $43.6 \pm 14.0$ & F4: 12.1 & $5.2 \pm 4.2$ & $\begin{array}{l}\text { F1-F3: } 1.42 \\
\text { F4: } 5.62\end{array}$ \\
\hline & $\operatorname{SVR}(-)$ & 342 & & & & & $\begin{array}{l}\text { F1-F3: } 0.85 \\
\text { F4: } 7.82\end{array}$ \\
\hline & $\operatorname{SVR}(+)$ & 715 & 60.5 & $46.9 \pm 11.5$ & F4: 15.6 & $5.2 \pm 3.0$ & $\begin{array}{c}\text { F1-F3: } 0.09 \\
F 4: 2.7\end{array}$ \\
\hline Huang et al.. , Taiwan, PS & $\operatorname{SVR}(+)$ & 642 & 54.4 & $\begin{array}{l}\leq F 3: 51.4 \pm 11.2 \\
F 4: 54.8 \pm 10.4\end{array}$ & F4: 13.4 & $\begin{array}{c}4.4 \\
(0.5-11.1)\end{array}$ & $\begin{array}{l}\leq F 3: 0.68 \\
F 4: 4.54\end{array}$ \\
\hline \multirow[t]{2}{*}{ El-Serag et al. ${ }^{12}$, USA, RS } & SVR (-) & 10,738 & 95.3 & 53.1 & Cirrhosis: 14.4 & 2.8 & 1.32 \\
\hline & $\operatorname{SVR}(+)$ & & & & & & $\begin{array}{l}0.33 \text { (1.39 in cirrhotics, } \\
0.13 \text { in non-cirrhotics) }\end{array}$ \\
\hline \multirow[t]{2}{*}{ Janjua et al. ${ }^{13}$, Canada, RS } & $\operatorname{SVR}(-)$ & 3,484 & 70.3 & $50.9(44.6-55.6)$ & $\mathrm{F} 4(7.5)$ & \multirow{2}{*}{$\begin{array}{c}5.6 \\
(0.5-12.9)\end{array}$} & 0.72 \\
\hline & SVR (+) & 4,663 & 65.5 & $49.3(41.7-54.8)$ & F4 (3.1) & & 0.11 \\
\hline
\end{tabular}

Values are presented as mean \pm standard deviation unless otherwise indicated.

RS, retrospective study; Tx., treatment; SVR, sustained virologic response; PS, prospective study. 
8,147 patients (cirrhotics in 5\%) who received IFN-based therapy were followed for a median of 5.6 years (range: $0.5-12.9$ ). The annual incidences for HCC were $0.11 \%$ and $0.72 \%$ in patient with SVR and non-SVR, respectively. Among the patients with SVR, cirrhosis, age $\geq 50$ years and male were associated with a higher HCC risk.

In a study ${ }^{14}$ that included 530 patients with biopsy-proven advanced fibrosis or cirrhosis (Table 2) in Europe and Canada who were treated with IFN-based regimen, $\mathrm{HCC}$ developed in 3.6\% (7/192) in SVR patients, 22.5\% (76/338) in the non-SVR group. Ten-year cumulative incidence rate of HCC was lower in patients with SVR compared without SVR (5.1\%; vs. $21.8 \% ; P<0.001)$. In patients with SVR, the annual incidence of HCC was lower than in those without SVR $(0.55 \%$, 95\% confidence interval [CI], 0.140.96 vs. $2.63 \%, 95 \% \mathrm{Cl}, 1.83-2.89, P<0.001)$. SVR was associated with reduced risk of all-cause mortality (hazard ratio [HR], $0.26 ; 95 \% \mathrm{Cl}, 0.14-0.49 ; P<0.001)$ and reduced risk of liver-related mortality or transplantation ( $\mathrm{HR}, 0.06 ; 95 \% \mathrm{Cl}, 0.02-0.19$; $P<0.001)$. van deer Meer et al. ${ }^{15}$ also reported the result of pooled data from Western $\mathrm{CHC}$ cohort $(\mathrm{n}=1,000)$ with bridging fibrosis or cirrhosis who attained SVR. During median follow-up of 5.7 (2.98.0) years, HCC and clinical disease progression, defined as liver failure, $\mathrm{HCC}$ or death were developed in 51 patients (5.1\%) and $101(10.1 \%)$ patients, respectively. The annual incidence of HCC was $0.9 \%(95 \% \mathrm{Cl}, 0.67-1.18)$. Old age ( $\geq 45)$, low platelet count $\left(<10 \times 10^{9} / \mathrm{L}\right)$ and diabetes mellitus were independently associated with development of HCC.

In a study ${ }^{16}$ that included patients with liver cirrhosis (Table 2), IFN therapy was performed in 1,214 HCV patients. During a mean 8 years of follow up period, HCC developed in 5.6\% (7/124) in SVR patients, $16.1 \%$ (122/759) in the non-SVR group. Liver-related complications (ascites, upper gastrointestinal bleeding, and hepatic encephalopathy) did not occur in patients with SVR, but in $14.1 \%$ (107/759) in non-SVR group. The incidence rates of liverrelated complications per 100 person-years of follow-up was 0 in SVR patients and $1.88(95 \% \mathrm{Cl}, 1.54-2.27)$ in non-SVR patients. The annual incidence rates of liver-related mortality were 0.19 $(95 \% \mathrm{Cl}, 0.02-0.71)$ in SVR and $1.44(95 \% \mathrm{Cl}, 0.14-1.78)$ in nonSVR patients. The clinical benefits of SVR in patient with HCV-related cirrhosis were validated by the prospective studies. ${ }^{17,18}$ Shiratori et al. prospectively followed for mean 6.8 years for 271 patients who received IFN treatment with HCV-related cirrhosis. ${ }^{17}$ In that cohort, the rates of HCC and liver-related death were lower in SVR patients than in those without SVR $(17.2 \%$ vs. $35.3 \%$, and $0 \%$ vs. $15 \%, P<0.001)$. Aleman et al..$^{18}$ also conducted a prospective study to evaluate long-term effect of SVR in 351 patients (110 patients with SVR, 193 patients without SVR and 48 patients without treatment) with HCV-related liver cirrhosis. During followup for $5.3 \pm 2.8$ years, $\mathrm{HCC}$ developed in six patients after achieving SVR. The annual incidence of HCC was $1.0 \%$. The annual inci-

Table 2. Summary of studies reporting annual incidence of hepatocellular carcinoma in advanced fibrosis or cirrhosis patients receiving interferonbased therapy

\begin{tabular}{|c|c|c|c|c|c|c|c|}
\hline Study & Response & $\begin{array}{l}\text { Patients } \\
\text { No. }\end{array}$ & $\begin{array}{c}\text { Male } \\
(\%)\end{array}$ & Age (years) & $\begin{array}{l}\text { Fibrosis (\%) } \\
\text { (F1/F2/F3/F4) }\end{array}$ & $\begin{array}{l}\text { Follow-up } \\
\text { (years) }\end{array}$ & $\begin{array}{c}\text { Annual incidence (\%) } \\
\text { (F1/F2/F3/F4) }\end{array}$ \\
\hline \multicolumn{8}{|l|}{$\begin{array}{l}\text { Studies that included patients } \\
\text { with advanced fibrosis (F3-F4 or } \\
\text { Ishak score 4-6) }\end{array}$} \\
\hline $\begin{array}{l}\text { van der Meer et al. }{ }^{14} \text {, Europe, } \\
\text { Canada, RS }\end{array}$ & $\begin{array}{l}\operatorname{SVR}(-) \\
\operatorname{SVR}(+)\end{array}$ & $\begin{array}{l}405 \\
125\end{array}$ & $\begin{array}{l}68 \\
75\end{array}$ & $\begin{array}{l}48(42-56) \\
47(43-54)\end{array}$ & $\begin{array}{l}0 / 0 / 44 / 56 \\
0 / 0 / 51 / 49\end{array}$ & $\begin{array}{c}5.8 \\
(3.1-8.5)\end{array}$ & $\begin{array}{l}2.63(1.83-2.89) \\
0.55(0.14-0.96)\end{array}$ \\
\hline $\begin{array}{l}\text { van der Meer et al. } .^{15}, \text { Europe, } \\
\text { Canada, RS }\end{array}$ & $\operatorname{SVR}(+)$ & 1,000 & 68 & $53(45-60)$ & 0/0/15/85 & $\begin{array}{c}5.7 \\
(2.9-8.0)\end{array}$ & $0.9(0.67-1.2)$ \\
\hline \multicolumn{8}{|l|}{$\begin{array}{l}\text { Studies that included only } \\
\text { patients with liver cirrhosis (F4) }\end{array}$} \\
\hline \multirow[t]{2}{*}{ Bruno et al. ${ }^{16}$, Italy, RS } & $\operatorname{SVR}(-)$ & 759 & 61.7 & $55.0 \pm 8.4$ & Cirrhosis only & 8.0 & $2.1(1.8-2.5)$ \\
\hline & SVR (+) & 124 & 73.4 & $52.6 \pm 9.6$ & & $(0.5-13.9)$ & $0.66(0.27-1.87)$ \\
\hline \multirow[t]{3}{*}{ Aleman et al. ${ }^{18}$, Sweden, PS } & No Tx. & 48 & 73 & $58 \pm 9$ & Cirrhosis only & $5.3 \pm 2.8$ & 4.0 (NA) \\
\hline & $\operatorname{SVR}(-)$ & 193 & 70 & $53 \pm 8$ & & & $2.3(\mathrm{NA})$ \\
\hline & SVR (+) & 110 & 72 & $50 \pm 9$ & & & $1.0(\mathrm{NA})$ \\
\hline
\end{tabular}

Values are presented as mean \pm standard deviation unless otherwise indicated.

RS, retrospective study; SVR, sustained virologic response; PS, prospective study; Tx., treatment; NA, not available. 
Seong Kyun $\mathrm{Na}$, et al.

Development and surveillance of HCC in SVR patients

dence of HCC was significantly higher in non-SVR and untreated patients with 2.3 and $4.0 \%$ ( $P=0.04$ and $P=0.03$, respectively).

Many studies, including meta-analysis, have also demonstrated that the risk of liver-related mortality, and the development of HCC decreases after SVR is attained with IFN-based regimens. A meta-analysis of 26 studies, ${ }^{2}$ enrolled 15,611 patients, showed that annual incidences of liver-related mortality, HCC and hepatic decompensation were $0.81 \%(95 \% \mathrm{Cl}, 0.55-1.07)$, 1.84\% (95\% $\mathrm{Cl}, 1.36-2.32)$ and $0.54 \%(95 \% \mathrm{Cl}, 0.11-0.97)$ in patients without SVR in any stage of fibrosis, respectively. Among the non-SVR patients in advanced fibrosis, rates of liver-related mortality (2.73\%/year; 95\% Cl, 1.38-4.08), HCC (3.22\%/year, 95\% Cl, 2.02-4.42), and hepatic decompensation (2.92\%/year; $95 \% \mathrm{Cl}$, 1.61-4.22) were substantial. In another meta-analysis of 12 studies, $^{3}$ encompassing 25,497 patients, HCC developed in 1.5\% $(145 / 9,185)$ of SVR patients and $6.2 \%(990 / 16,312)$ in non-SVR patients in patient with any stage of fibrosis. The annual incidence of HCC was $0.33 \%(95 \% \mathrm{Cl}, 0.22-0.50)$ among patients with SVR compared with $1.67 \%(95 \% \mathrm{Cl}, 1.15-2.42)$ in those without SVR. SVR was associated with reduced risk of HCC of 0.24 (95\% $\mathrm{Cl}, 0.18-0.31)$. In a further meta-analysis of 6 studies including 2,649 patients with advanced fibrosis, ${ }^{3}$ HCC developed in 4.2\% $(32 / 756)$ and $17.8 \%(337 / 1,893)$ in patients with SVR and without SVR, respectively. The annual incidences of HCC were $1.05 \%$ $(95 \% \mathrm{Cl}, 0.73-1.50)$ and $3.3 \%(95 \% \mathrm{Cl}, 2.61-4.16)$ in patients with SVR and without SVR, respectively.

In a recently published prospective study, ${ }^{19}$ 1,323 patients with biopsy- proven HCV-related liver cirrhosis were followed for median 53 months after IFN-based treatment. SVR was associated with a decreased incidence of HCC (HR, 0.29; 95\% Cl, 0.19-0.43; $P<0.001)$ and hepatic decompensation ( $\mathrm{HR}, 0.26 ; 95 \% \mathrm{Cl}, 0.17-$ $0.39 ; P<0.001)$ compared with patients without an SVR. SVR decreased the overall mortality $(\mathrm{HR}, 0.27 ; 95 \% \mathrm{Cl}, 018-0.42$; $P<0.001)$ compared with patients without SVR and death from liver-related and non-liver-related causes.

\section{OUTCOMES OF PATIENTS WITH SVR AFTER DAA-BASED THERAPY}

DAA are very safe and highly effective (>95\% SVR) against all genotypes of HCV. ${ }^{8-10}$ They are applicable to all patients with $\mathrm{HCV}$, including those with decompensated liver disease and end stage renal disease who are unfit to IFN therapy. ${ }^{6,7}$ The introduction of DAA into hepatitis $C$ treatment is expected to increase the clinical benefit in terms of prevention of progression of chronic liver disease and the development of HCC. However, a few recent studies have raised concerns that DAA might increase the risk of HCC in some patients. ${ }^{20-22}$ However, recent retrospective studies $^{23-25}$ and meta-analyses ${ }^{26,27}$ concluded that there is no evidence that HCC occurrence or recurrence after treatment for HCC is different between patients receiving DAA or IFN therapy in patients with SVR treated with DAA or IFN.

Table 3 summarized the outcome of SVR patients who received DAA therapy. In a large retrospective cohort study of HCV patients ( $n=22,500$ ) treated with DAA using Veterans health administration data, SVR was associated with a $76 \%$ reduction in risk of HCC compared with those who did not achieve SVR. ${ }^{28}$ Patients with SVR had a significantly reduced risk of HCC compared with patients without SVR (annual incidence $0.90 \%$ vs. 3.45\%; HR, $0.28,95 \% \mathrm{Cl}, 0.22-0.36)$. The annual HCC incidences were $0.34 \%(95 \% \mathrm{Cl}, 0.24-0.45)$ and $1.82 \%(95 \% \mathrm{Cl}, 1.52-2.12)$ in non-cirrhotic patients and cirrhotic SVR patients, respectively. Even though the follow-up duration was short, the preventive effect of SVR increased over time. Li et al. ${ }^{23}$ retrospectively analyzed 17,836 patients treated with IFN or DAA. Among all treated patients, risk of HCC was not higher in the DAA group compared to the IFN group. Among cirrhotic patients (defined by FIB-4 >3.5) with SVR, annual incidence of HCC was not different in the DAA group compared to the IFN group (2.12\% vs. $2.28 \%$ ). In cirrhotic patients with SVR, old age, use of proton-pump inhibitor, and $\operatorname{AFP}(>20)$ were independent risk factors for HCC. Ioannou et al. ${ }^{24}$ analyzed 62,354 who were treated with IFN only ( $n=35,871)$, DAA+IFN $(n=4,535)$ and DAA only $(n=21,948)$. In all regimen, the annual incidences of HCC was $0.43 \%$ and $1.14 \%$ in SVR and non-SVR patients, respectively. They are not different among three treatment regimen. In cirrhotic patients, the annual incidence was lower in SVR patients compared to those without SVR (1.97\% vs. 3.25\%). In non-cirrhotic patients, the annual incidence was lower in SVR patients compared to those without SVR $(0.24 \%$ vs. $0.87 \%$ ). In patients with DAA, HCC incidence was $0.92 \%$ in the SVR group and $5.19 \%$ in the non-SVR group.

\section{RISK FACTORS FOR HCC IN CHC PATIENT WITH SVR AFTER ANTIVIRAL THERAPY}

Table 4 summarizes the risk factors for HCC in patients with CHC who achieved SVR after antiviral treatment. Among them, old age and $\geq F 3 / F 4$ fibrosis were most important risk factors for 
Table 3. Summary of studies that reported annual incidences of hepatocellular carcinoma (HCC) in patients with direct-acting antiviral agent (DAA)based therapy

\begin{tabular}{|c|c|c|c|c|c|c|c|c|c|}
\hline Study & Treatment & Response & $\begin{array}{l}\text { Patients } \\
\text { No. }\end{array}$ & $\begin{array}{c}\text { Male } \\
(\%)\end{array}$ & $\begin{array}{c}\text { Age } \\
\text { (years) }\end{array}$ & Fibrosis (\%) & $\begin{array}{l}\text { Follow-up } \\
\text { (years) }\end{array}$ & $\begin{array}{c}\text { Annual } \\
\text { incidence }\end{array}$ & Risk factors for HCC \\
\hline \multirow{2}{*}{$\begin{array}{l}\text { Kanwal et } \\
\text { al. }^{28}, \text { USA, } \\
\text { RS }\end{array}$} & \multirow[t]{2}{*}{ DAA } & SVR (-) & 2,982 & 97.6 & $61.2 \pm 5.8$ & $F 4: 42.6$ & 1.0 (mean) & 3.45 & \\
\hline & & $\operatorname{SVR}(+)$ & 19,518 & 96.6 & $61.6 \pm 6.1$ & F4: 38.4 & & $\begin{array}{c}0.9 \\
\text { F1-3: } 0.34 \\
F 4: 1.82\end{array}$ & Alcohol abuse, cirrhosis \\
\hline \multirow{5}{*}{$\begin{array}{l}\text { Li et al. }{ }^{23}, \text { USA, } \\
\text { RS }\end{array}$} & \multirow[t]{2}{*}{ DAA } & SVR (-) & 222 & \multirow[t]{2}{*}{96.6} & \multirow[t]{2}{*}{$62(58-65)$} & \multirow{2}{*}{$\begin{array}{c}\mathrm{F} 4 \text { (FIB-4 >3.5): } \\
19.9\end{array}$} & \multirow[t]{2}{*}{1.1 (mean) } & 2.11 (F4: 6.28) & \multirow[t]{5}{*}{ Age, AFP $>20$} \\
\hline & & $\operatorname{SVR}(+)$ & 5,612 & & & & & 0.74 (F4: 2.28) & \\
\hline & \multirow[t]{3}{*}{ IFN } & No Tx. & 8,468 & 97.2 & $58(54-62)$ & $\begin{array}{c}\mathrm{F} 4(\mathrm{FIB}-4>3.5): \\
14.6\end{array}$ & 7.4 (mean) & 1.09 (F4: 4.53) & \\
\hline & & SVR (-) & 1,180 & 95.9 & $54(50-57)$ & F4 (FIB-4 >3.5): & & 1.48 (F4: 4.89) & \\
\hline & & $\operatorname{SVR}(+)$ & 2,354 & & & 13.1 & & 0.35 (F4: 2.12) & \\
\hline \multirow{6}{*}{$\begin{array}{l}\text { loannou et } \\
\text { al. }^{24}, \text { USA, } \\
\text { RS }\end{array}$} & \multirow[t]{2}{*}{ DAA } & $\operatorname{SVR}(-)$ & 2,039 & 98.3 & $60.7 \pm 6.3$ & F4: 36 & 6.1 (mean) & 5.19 & \multirow[t]{6}{*}{ NA } \\
\hline & & $\operatorname{SVR}(+)$ & 19,909 & 96.6 & $61.0 \pm 6.7$ & F4: 22.6 & & 0.92 & \\
\hline & \multirow[t]{2}{*}{ IFN } & SVR (-) & 22,833 & 97 & $52.4 \pm 6.2$ & F4: 13.5 & & 1.07 & \\
\hline & & $\operatorname{SVR}(+)$ & 11,988 & 95.7 & $52.4 \pm 6.8$ & $F 4: 7.8$ & & 0.28 & \\
\hline & \multirow[t]{2}{*}{$\mathrm{DAA}+\mathrm{IFN}$} & $\operatorname{SVR}(-)$ & 27,694 & 97.0 & $53.4 \pm 6.1$ & F4: 16.1 & & $\begin{array}{c}\text { F1-F3: } 0.87 \\
\text { F4: } 3.25\end{array}$ & \\
\hline & & $\operatorname{SVR}(+)$ & 34,660 & 96.3 & $57.7 \pm 6.7$ & F4: 17.3 & & $\begin{array}{c}\text { F1-F3: } 0.24 \\
\text { F4: } 1.97\end{array}$ & \\
\hline $\begin{array}{c}\text { Akuta et al. }{ }^{47}, \\
\text { Japan, RS }\end{array}$ & $\mathrm{DAA} \pm \mathrm{IFN}$ & $\operatorname{SVR}(+)$ & 958 & 46.7 & $64(20-88)$ & NA & NA & 0.74 & $\mathrm{FIB}-4 \geq 2.7, \mathrm{BMI} \geq 23$ \\
\hline
\end{tabular}

RS, retrospective study; SVR, sustained virologic response; IFN, interferon; TX., treatment; FIB-4, fibrosis-4; AFP, alpha-fetoprotein; NA, not available; BMI, body mass index.

HCC in most studies. Other risk factors for HCC include male, diabetes mellitus, alcohol abuse, high gamma-glutamyltransferase (GGT) and AFP.

The annual incidence of HCC increased up to $2.5-4.5 \%$ even in patient with SVR in advanced fibrosis or liver cirrhosis. ${ }^{4,5}$ In some studies, the risk of HCC after SVR was also increased in patients with F2 fibrosis. ${ }^{4,29}$ In contrast, the annual risk of HCC in patients with SVR in $\leq$ F2 fibrosis might be less than $0.5 \%$ (Table 1).11,29-32 Therefore, based on the current evidences, routine surveillance for $\mathrm{HCC}$ in patients with FO-F2 fibrosis is not recommended. ${ }^{33-35}$

However, Japanese studies have reported that HCC developed in several number of patients with F1/F2 fibrosis even after SVR. In a study by Yamashita et al., ${ }^{29} 562$ SVR patients were followed for median 4.8 years after IFN-based treatment. HCC developed in 31 patients (5.5\%) after completion of IFN therapy. Among them, 35.5\% (11/31) patients had pretreatment fibrosis F1 or F2. In their study, $\geq \mathrm{F} 2$ fibrosis was an independent risk factor for HCC. Ikeda et al. ${ }^{31}$ reported that 12 of $706(1.7 \%)$ of patients with F1/F2 fibrosis developed HCC with an annual incidence of $0.27 \%$ and $0.47 \%$ in $F 1$ and $F 2$, respectively. In another Japanese study, ${ }^{32}$ HCC developed in $3 \%(36 / 1,094)$ in patients with SVR after IFN therapy during median follow-up of 37 months (17-141 months). The cumulative rates of HCC according to fibrosis stage (F0/1, F2, $\mathrm{F} 3$, and $\mathrm{F} 4$ ) were $2 \%, 7 \%, 17 \%$, and $22 \%$ at 10 years, respectively. Furthermore, the cumulative rates of HCC by fibrosis stage in males were $5 \%, 10 \%, 16 \%$, and $20 \%$ at 10 years for $\mathrm{F} 0 / 1, \mathrm{~F} 2$, $\mathrm{F} 3$, and F4, respectively $(P=0.009)$.

There have been studies ${ }^{4,11,30}$ that the annual incidence of HCC is higher than that of $\mathrm{F} 2$ fibrosis alone when the risk factors of other HCC are added in SVR patients with F2 fibrosis. Yoshida et al. ${ }^{30}$ reported that the annual incidences of HCC was $0.1 \%$ in patients with $\mathrm{F} 2$ fibrosis, however, the annual incidence increased to $1.18 \%$ in men aged 60 years or older with $\mathrm{F} 2$ fibrosis. Huang et al. ${ }^{4}$ reported that age $\geq 60$, high $\mathrm{GGT}$ and $\mathrm{F} \geq 2$ fibrosis were independent risk factors for HCC in non-cirrhotic patients. ${ }^{4}$ In non-cirrhotic patients with 1 risk factor (age $\geq 60$ or high GGT), the annual incidence of HCC was $1.22 \%$. In non-cirrhotic patients with 2 risk factors, the annual incidence of HCC increased to $2.8 \%$. In 
Seong Kyun $\mathrm{Na}$, et al.

Development and surveillance of HCC in SVR patients

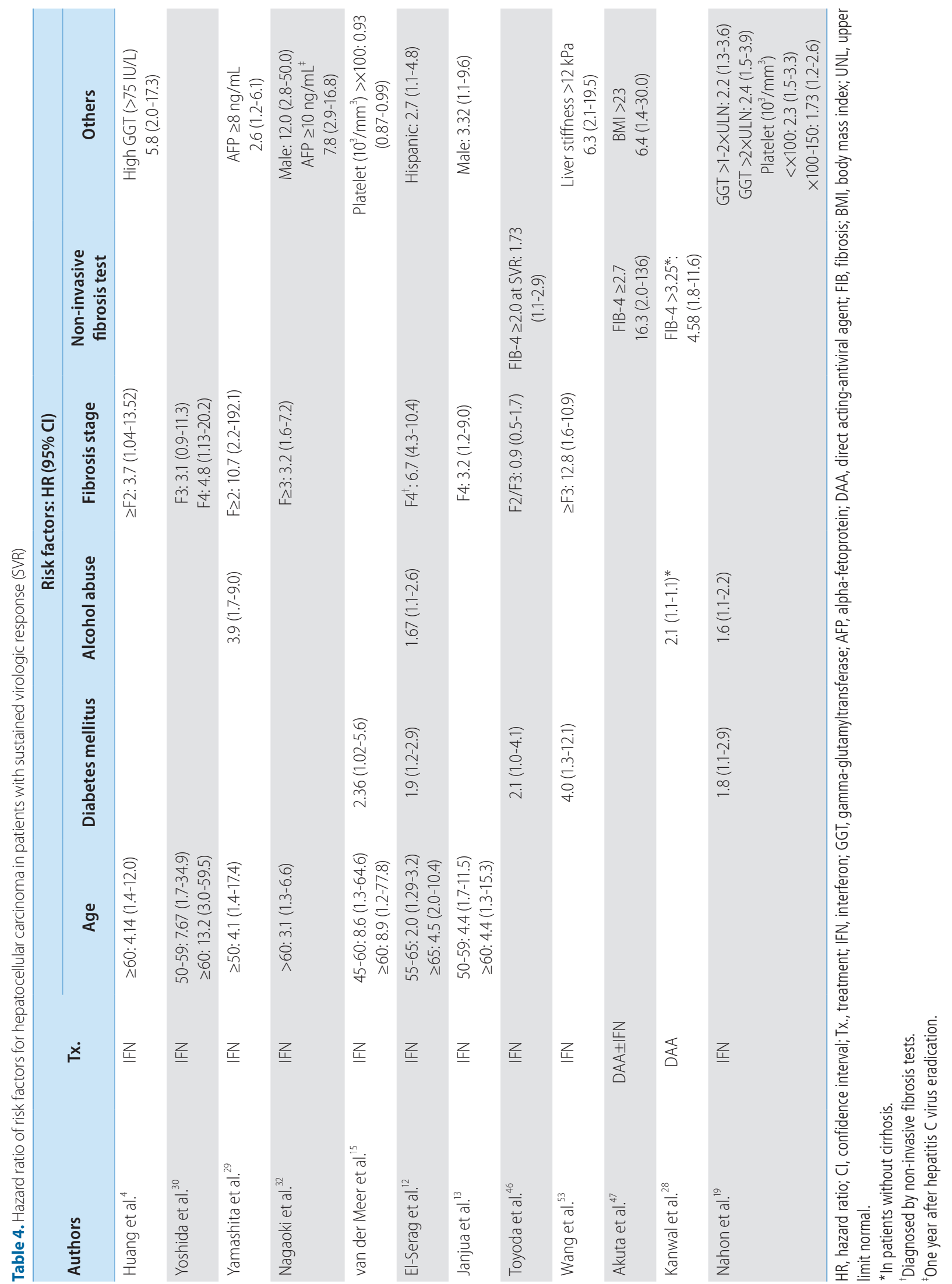


patients with SVR without HCV-related cirrhosis, the annual incidence of HCC was $1.22 \%$ in patients older than 60 years of age and $0.14 \%$ in patients less than 60 years of age. ${ }^{4}$

The 5-year cumulative risk of HCC was higher in SVR patients with metabolic features (body mass index of $25 \mathrm{~kg} / \mathrm{m}^{2}$ or greater and/or diabetes and/or dyslipidemia) than in those without any metabolic features (30\% vs. 8.8\%; $P=0.042) .{ }^{19}$ Whereas, HCC risk was similar in non-SVR patients with and without metabolic features (13.9\% vs. $20.6 \% ; P=0.91)$. These findings suggest that HCC surveillance tests might be needed in some patients with $\leq$ F2 fibrosis with other risk factors for HCC.

The problem is that most of the studies reported so far are based on studies in $\mathrm{CHC}$ patients with biopsy-proven liver fibrosis, and it is practically impossible to perform biopsy to all patients before antiviral therapy in clinical practice. Recent guideline ${ }^{33}$ recommends non-invasive fibrosis tests, such as liver stiffness measurement (LSM), aspartate aminotransferase-to-platelet ratio index (APRI), fibrosis-4 (FIB-4) index and commercial assays, instead of liver biopsy to assess liver disease severity in $\mathrm{CHC}$ patients prior to therapy. LSM is the most accurate non-invasive method for detecting cirrhosis in patients with viral hepatitis. ${ }^{36}$ In low- and middle-income countries, as well as in settings where treatment expands outside of specialty clinics, if LSM was not available, APRI and FIB-4 are recommended ${ }^{33}$ because they are generally available, simple and cheap, and the result is reliable. $^{37-43}$ The cut-off values of LSM, APRI and FIB-4 which predict the advanced fibrosis ( $\geq F 3$ ), are $9.5 \mathrm{kPa}, 1.5$ and 3.25 . $^{33,39,43-45}$

Non-invasive fibrosis tests have been reported to predict the risk of HCC in patients with SVR (Table 5). ${ }^{28,46-48}$ Correlation between non-invasive fibrosis test and development of HCC is summarized in Table 4. Kobayashi et al. ${ }^{48}$ retrospectively analyzed 605 patients with SVR after treatment with DAA $(n=77)$ or IFN
( $n=528)$. The cumulative incidence of $\mathrm{HCC}$ in patients with FIB-4 $>3.25$ was not different between the DAA and IFN groups $(9.66 \%$ vs. $8.37 \%$ ). The cumulative incidence of $\mathrm{HCC}$ at 5 years in patients with FIB- $4 \leq 3.25$ was $0 \%$ and $1.05 \%$ in DAA and IFN groups, respectively. According to Kanwal et al, ${ }^{28}$ alcohol abuse, diabetes, FIB-4 $>3.25$ were independent risk factors for HCC. Patients with FIB-4 $>3.25$ had an annual HCC incidence of $2.16 \%(95 \% \mathrm{Cl}$, $1.78-2.54)$ compared with $0.45 \%(95 \% \mathrm{Cl}, 0.32-0.59)$ in patients with FIB-4 1.45 to 3.25 , and $0.3 \%(95 \% \mathrm{Cl}, 0.14-0.46)$ in patients with FIB-4 $\leq 1.45$.

Some studies have shown that non-invasive liver fibrosis after treatment is more useful than before treatment. ${ }^{46,49,50}$ Toyoda et al. $^{46}$ evaluated the usefulness of FIB-4 at the time of SVR as a risk factor for the HCC after median follow-up of 7.2 years in patients with SVR after IFN treatment. HCC developed in 3.5\% (18/522) patients. The cumulative incidence of $\mathrm{HCC}$ was $1.2 \%$ at 5 years and $4.3 \%$ at 10 years. The presence of diabetes mellitus (risk ratio 2.08; $P=0.045)$ and FIB-4 at the time of SVR, but not pretreatment liver fibrosis were associated with a higher risk of HCC. Yu et al. ${ }^{50}$ evaluated the predictive value of APRI at 6 months after end of treatment (APRI-M6). Among the SVR group, the 5-year, and 10-year cumulative incidence of HCC was significantly higher in patients with APRI-M6 $>0.5$ compared to those with APRI-M6 $<0.5(10.5 \%, 25.7 \%$ vs. $1.1 \%, 1.1 \% ; P<0.001)$.

LSM might be a promising test to predict the risk of HCC during active viral replication. ${ }^{37,51,52}$ In a study ${ }^{53}$ from Taiwan of 278 patients with SVR during a median follow-up period of 7.6 years, HCC developed in $17.4 \%(4 / 23)$ in patients with $\geq 12 \mathrm{kPa}$ and even in $4.9 \%(5 / 103)$ with liver stiffness $<12 \mathrm{kPa}$, respectively. Another study ${ }^{54}$ from Korea suggested that stiffness threshold to predict $\mathrm{HCC}$ development was $\geq 7.0 \mathrm{kPa}$. So far, therefore there is no reliable threshold level of liver stiffness to predict HCC development

Table 5. Noninvasive fibrosis tests predicting hepatocellular carcinoma (HCC) after sustained virologic response (SVR)

\begin{tabular}{|c|c|c|c|c|}
\hline Study & Methods & Treatment & $\begin{array}{l}\text { Patient No. } \\
\text { (\% liver cirrhosis) }\end{array}$ & HCC risk \\
\hline $\begin{array}{l}\text { Kobayashi et al. }{ }^{48} \text {, Japan, } \\
\text { RS }\end{array}$ & FIB-4 & IFN, DAA & $77(N A)$ & $\begin{array}{l}\text { FIB-4 }>3.25 \text { : } 5 \text {-year incidence of } 8.37 \% \text { in IFN group and } 9.66 \% \text { in } \\
\text { DAA group } \\
\text { FIB- } 4 \leq 3.25: 5 \text {-year incidence of } 1.05 \% \text { in IFN group and } 0 \% \text { in DAA } \\
\text { group }\end{array}$ \\
\hline Wang et al. ${ }^{53}$, Taiwan, RS & LSM & IFN & $376(N A)$ & LS >12 kPa vs. $\leq 12$ kPa: OR $6.3(95 \%$ Cl, 2.09-19.49, $P=0.001)$ \\
\hline Toyoda et al. ${ }^{46}$, Japan, RS & FIB-4 & IFN & $522(0)$ & FIB-4 index at SVR24 $\geq 2.0$ vs. $<2.0: 5$ year incidence $3.4 \%$ vs. $0 \%$ \\
\hline Kanwal et al. ${ }^{28}$, USA, RS & FIB-4 & DAA & $19,518(38.4)$ & FIB- $4>3.25$ vs. $\leq 3.25$ : annual incidence of $2.16 \%$ vs. $0.3-0.45 \%$ \\
\hline Yu et al. $^{50}$,Taiwan, RS & APRI & IFN & $483(12.6)$ & Post-treatment APRI $>0.5$ vs. $<0.5: 5$ year incidence of $10.5 \%$ vs. $1.1 \%$ \\
\hline
\end{tabular}

RS, retrospective study; FIB, fibrois; IFN, interferon; DAA, direct acting-antiviral agent; NA, not available; LSM, liver stiffness measurement; LS, liver stiffness; $\mathrm{OR}$, odds ratio; $\mathrm{Cl}$, confidence interval; $\mathrm{APRI}$, aspartate aminotransferase-to-platelet ratio index. 
Seong Kyun $\mathrm{Na}$, et al.

Development and surveillance of HCC in SVR patients

in patients with SVR.

In a recent study of 115 SVR patients who underwent serial liver biopsy, Tachi et al. demonstrated that APRI or FIB-4 after SVR reflected liver fibrosis in patients with SVR ${ }^{55}$ However, non-invasive blood fibrosis tests have demonstrated poor correlation with postSVR liver biopsy findings in another study. ${ }^{56}$ Therefore, non-invasive blood fibrosis tests after therapy are not recommended to assess the fibrosis stage after therapy, as they are unreliable in this setting. $^{33}$

\section{SURVEILLANCE FOR HCC IN PATIENTS WITH CHC WHO HAVE ACQUIRED SVR AFTER ANTI- VIRAL THERAPY}

To decide whether to enter a patient into a surveillance program, the clinician should consider not only the risk level of HCC, but also the age, overall health status, and medical cost. ${ }^{57}$ Until now, a definite threshold level of annual incidence of HCC is not clear, but it was reported that surveillance is cost-effective if the annual incidence is $\geq 1.5-2 \%$ per year in patients with HCV-related liver cirrhosis. ${ }^{58,59}$ However, Lin et al. reported that surveillance for HCC in patient with HCV-related liver cirrhosis was cost-effective regardless of annual incidence. ${ }^{60}$ There is little information about cost-effective analysis in patients with non-cirrhotic CHC, especially those who achieve SVR after treatment. Therefore, it is more difficult to determine the criteria for surveillance in these groups. ${ }^{57}$ Nonetheless, several guidelines recommend surveillance for HCC if the annual incidence is $\geq 1.5 \%$ or advanced fibrosis or cirrhosis before treatment even after SVR after antiviral therapy. $33,34,61-63$

Combining the results reported so far and the recommendation of several guidelines, surveillance for HCC should be performed in the following patients with SVR after antiviral treatment until new evidence is available: 1) biopsy proven advanced fibrosis (F3) or liver cirrhosis (F4); 2) clinical evidences of liver cirrhosis, such as ascites, esophageal/gastric varices; 3 ) splenomegaly with thrombocytopenia; 4) noninvasive fibrosis test suggesting advanced fibrosis (FIB-4 $\geq 3.25, A P R I \geq 1.5$, LSM $9.5 \mathrm{kPa}$ et al.). So far, there is not enough evidence in patient with $\mathrm{F} 2$ fibrosis, but surveillance would be considered if there are additional risk factors for HCC, such as old age ( $\geq 60$ years), diabetes mellitus, and alcohol abuse et al.

\section{CONCLUSION}

Even though, SVR after antiviral therapy dramatically decreased the risk of hepatic decompensation, HCC and death, the risk of $\mathrm{HCC}$ is not eliminated. The annual incidence of HCC in patients with liver cirrhosis have been estimated to be up to $4.5 \%$ even in patients with SVR. DAAs are applicable to all patients with HCV, including old age and more advanced liver disease. The development of HCC might be increasing even in patients with SVR. Therefore, identifying the high-risk groups of HCC and monitoring them continuously is an important clinical issue.

\section{Authors' contribution}

SK Na and BC Song were responsible for conception or design of the work, data collection, data analysis and interpretation, drafting the article, critical revision of the article, and final approval of the version to be published.

\section{Acknowledgements}

This work was supported by the 2019 education, research and student guidance grant funded by Jeju National University.

\section{Conflicts of Interest}

The authors don't have any conflict of interest.

\section{REFERENCES}

1. Lavanchy D. Evolving epidemiology of hepatitis C virus. Clin Microbiol Infect 2011;17:107-115.

2. Singal AG, Volk ML, Jensen D, Di Bisceglie AM, Schoenfeld PS. A sustained viral response is associated with reduced liver-related morbidity and mortality in patients with hepatitis C virus. Clin Gastroenterol Hepatol 2010;8:280-288.e1.

3. Morgan RL, Baack B, Smith BD, Yartel A, Pitasi M, Falck-Ytter Y. Eradication of hepatitis $C$ virus infection and the development of hepatocellular carcinoma: a meta-analysis of observational studies. Ann Intern Med 2013;158(5 Pt 1):329-337.

4. Huang CF, Yeh ML, Tsai PC, Hsieh MH, Yang HL, Hsieh MY, et al. Baseline gamma-glutamyl transferase levels strongly correlate with hepatocellular carcinoma development in non-cirrhotic patients with successful hepatitis C virus eradication. J Hepatol 2014;61:67-74.

5. Yu ML, Lin SM, Chuang WL, Dai CY, Wang JH, Lu SN, et al. A sustained virological response to interferon or interferon/ribavirin reduces hepatocellular carcinoma and improves survival in chronic hepatitis C: a nationwide, multicentre study in Taiwan. Antivir Ther 
2006;11:985-994

6. Gane E, Lawitz E, Pugatch D, Papatheodoridis G, Bräu N, Brown A, et al. Glecaprevir and pibrentasvir in patients with $\mathrm{HCV}$ and severe renal impairment. N Engl J Med 2017;377:1448-1455.

7. Curry MP, O'Leary JG, Bzowej N, Muir AJ, Korenblat KM, Fenkel JM, et al. Sofosbuvir and velpatasvir for HCV in patients with decompensated cirrhosis. N Engl J Med 2015;373:2618-2628.

8. Afdhal N, Zeuzem S, Kwo P, Chojkier M, Gitlin N, Puoti M, et al. Ledipasvir and sofosbuvir for untreated HCV genotype 1 infection. N Engl J Med 2014;370:1889-1898

9. Forns $X$, Lee SS, Valdes J, Lens $S$, Ghalib R, Aguilar H, et al. Glecaprevir plus pibrentasvir for chronic hepatitis $C$ virus genotype 1, 2, 4, 5, or 6 infection in adults with compensated cirrhosis (EXPEDITION-1): a single-arm, open-label, multicentre phase 3 trial. Lancet Infect Dis 2017;17:1062-1068.

10. Zeuzem S, Foster GR, Wang S, Asatryan A, Gane E, Feld JJ, et al. Glecaprevir-pibrentasvir for 8 or 12 weeks in HCV genotype 1 or 3 infection. N Engl J Med 2018;378:354-369.

11. Yoshida $H$, Shiratori $Y$, Moriyama M, Arakawa $Y$, Ide $T$, Sata M, et al. Interferon therapy reduces the risk for hepatocellular carcinoma: national surveillance program of cirrhotic and noncirrhotic patients with chronic hepatitis C in Japan. IHIT Study Group. Inhibition of Hepatocarcinogenesis by Interferon Therapy. Ann Intern Med 1999:131:174-181.

12. El-Serag HB, Kanwal F, Richardson P, Kramer J. Risk of hepatocellular carcinoma after sustained virological response in Veterans with hepatitis C virus infection. Hepatology 2016;64:130-137.

13. Janjua NZ, Chong M, Kuo M, Woods R, Wong J, Yoshida EM, et al. Long-term effect of sustained virological response on hepatocellular carcinoma in patients with hepatitis C in Canada. J Hepatol 2017;66:504-513.

14. van der Meer AJ, Veldt BJ, Feld JJ, Wedemeyer H, Dufour JF, Lammert $F$, et al. Association between sustained virological response and all-cause mortality among patients with chronic hepatitis $C$ and advanced hepatic fibrosis. JAMA 2012;308:2584-2593.

15. van der Meer AJ, Feld JJ, Hofer H, Almasio PL, Calvaruso V, Fernández-Rodríguez $\mathrm{CM}$, et al. Risk of cirrhosis-related complications in patients with advanced fibrosis following hepatitis C virus eradication. J Hepatol 2017;66:485-493.

16. Bruno S, Stroffolini T, Colombo M, Bollani S, Benvegnù L, Mazzella $G$, et al. Sustained virological response to interferon-alpha is associated with improved outcome in HCV-related cirrhosis: a retrospective study. Hepatology 2007;45:579-587.

17. Shiratori Y, Ito Y, Yokosuka O, Imazeki F, Nakata R, Tanaka N, et al. Antiviral therapy for cirrhotic hepatitis C: association with reduced hepatocellular carcinoma development and improved survival. Ann Intern Med 2005;142:105-114.

18. Aleman S, Rahbin N, Weiland O, Davidsdottir L, Hedenstierna M,
Rose $N$, et al. A risk for hepatocellular carcinoma persists longterm after sustained virologic response in patients with hepatitis Cassociated liver cirrhosis. Clin Infect Dis 2013;57:230-236.

19. Nahon P, Bourcier V, Layese R, Audureau E, Cagnot C, Marcellin P, et al. Eradication of hepatitis $C$ virus infection in patients with cirrhosis reduces risk of liver and non-liver complications. Gastroenterology 2017;152:142-156.e2.

20. Conti F, Buonfiglioli F, Scuteri A, Crespi C, Bolondi L, Caraceni P, et al. Early occurrence and recurrence of hepatocellular carcinoma in HCV-related cirrhosis treated with direct-acting antivirals. J Hepatol 2016;65:727-733.

21. Reig $M$, Mariño $Z$, Perelló $C$, Iñarrairaegui $M$, Ribeiro $A$, Lens $S$, et al. Unexpected high rate of early tumor recurrence in patients with HCV-related HCC undergoing interferon-free therapy. J Hepatol 2016;65:719-726.

22. Ravi S, Axley P, Jones D, Kodali S, Simpson H, McGuire BM, et al. Unusually high rates of hepatocellular carcinoma after treatment with direct-acting antiviral therapy for hepatitis $\mathrm{C}$ related cirrhosis. Gastroenterology 2017;152:911-912.

23. Li DK, Ren Y, Fierer DS, Rutledge S, Shaikh OS, Lo Re V 3rd, et al. The short-term incidence of hepatocellular carcinoma is not increased after hepatitis $C$ treatment with direct-acting antivirals: an ERCHIVES study. Hepatology 2018;67:2244-2253.

24. Ioannou GN, Green PK, Berry K. HCV eradication induced by directacting antiviral agents reduces the risk of hepatocellular carcinoma. J Hepatol 2018;68:25-32.

25. Nagaoki Y, Imamura M, Aikata H, Daijo K, Teraoka Y, Honda F, et al. The risks of hepatocellular carcinoma development after HCV eradication are similar between patients treated with peg-interferon plus ribavirin and direct-acting antiviral therapy. PLoS One 2017;12:e0182710.

26. Waziry R, Hajarizadeh B, Grebely J, Amin J, Law M, Danta M, et al. Hepatocellular carcinoma risk following direct-acting antiviral HCV therapy: a systematic review, meta-analyses, and meta-regression. J Hepatol 2017;67:1204-1212.

27. Mettke F, Schlevogt B, Deterding K, Wranke A, Smith A, Port K, et al. Interferon-free therapy of chronic hepatitis $C$ with direct-acting antivirals does not change the short-term risk for de novo hepatocellular carcinoma in patients with liver cirrhosis. Aliment Pharmacol Ther 2018;47:516-525.

28. Kanwal F, Kramer J, Asch SM, Chayanupatkul M, Cao Y, El-Serag HB. Risk of hepatocellular cancer in HCV patients treated with directacting antiviral agents. Gastroenterology 2017;153:996-1005.e1.

29. Yamashita N, Ohho A, Yamasaki A, Kurokawa M, Kotoh K, Kajiwara E. Hepatocarcinogenesis in chronic hepatitis $C$ patients achieving a sustained virological response to interferon: significance of lifelong periodic cancer screening for improving outcomes. J Gastroenterol 2014;49:1504-1513. 
Seong Kyun $\mathrm{Na}$, et al.

Development and surveillance of HCC in SVR patients

30. Yoshida H, Tateishi R, Arakawa Y, Sata M, Fujiyama S, Nishiguchi $S$, et al. Benefit of interferon therapy in hepatocellular carcinoma prevention for individual patients with chronic hepatitis C. Gut 2004;53:425-430.

31. Ikeda M, Fujiyama S, Tanaka M, Sata M, Ide T, Yatsuhashi H, et al. Risk factors for development of hepatocellular carcinoma in patients with chronic hepatitis $C$ after sustained response to interferon. J Gastroenterol 2005;40:148-156.

32. Nagaoki Y, Aikata H, Nakano N, Shinohara F, Nakamura Y, Hatooka $M$, et al. Development of hepatocellular carcinoma in patients with hepatitis C virus infection who achieved sustained virological response following interferon therapy: a large-scale, long-term cohort study. J Gastroenterol Hepatol 2016;31:1009-1015.

33. European Association for the Study of the Liver. EASL recommendations on treatment of hepatitis C 2018. J Hepatol 2018;69:461-511.

34. AASLD/IDSA HCV Guidance Panel. Hepatitis C guidance: AASLDIDSA recommendations for testing, managing, and treating adults infected with hepatitis C virus. Hepatology 2015;62:932-954.

35. Jacobson IM, Lawitz E, Kwo PY, Hézode C, Peng CY, Howe AYM, et al. Safety and efficacy of elbasvir/grazoprevir in patients with hepatitis C virus infection and compensated cirrhosis: an integrated analysis. Gastroenterology 2017;152:1372-1382.e2.

36. European Association for the Study of the Liver; Asociacion Latinoamericana para el Estudio del Higado. EASL-ALEH Clinical Practice Guidelines: non-invasive tests for evaluation of liver disease severity and prognosis. J Hepatol 2015;63:237-264.

37. Masuzaki R, Tateishi R, Yoshida H, Goto E, Sato T, Ohki T, et al. Prospective risk assessment for hepatocellular carcinoma development in patients with chronic hepatitis $\mathrm{C}$ by transient elastography. Hepatology 2009;49:1954-1961.

38. Lin ZH, Xin YN, Dong QJ, Wang Q, Jiang XJ, Zhan SH, et al. Performance of the aspartate aminotransferase-to-platelet ratio index for the staging of hepatitis C-related fibrosis: an updated meta-analysis. Hepatology 2011;53:726-736.

39. Sterling RK, Lissen E, Clumeck N, Sola R, Correa MC, Montaner J, et al. Development of a simple noninvasive index to predict significant fibrosis in patients with HIV/HCV coinfection. Hepatology 2006;43:1317-1325.

40. Sandrin L, Fourquet B, Hasquenoph JM, Yon S, Fournier C, Mal F, et al. Transient elastography: a new noninvasive method for assessment of hepatic fibrosis. Ultrasound Med Biol 2003;29:1705-1713.

41. Holmberg SD, Lu M, Rupp LB, Lamerato LE, Moorman AC, Vijayadeva $\mathrm{V}$, et al. Noninvasive serum fibrosis markers for screening and staging chronic hepatitis C virus patients in a large US cohort. Clin Infect Dis 2013;57:240-246.

42. Vallet-Pichard A, Mallet V, Nalpas B, Verkarre V, Nalpas A, DhalluinVenier $\mathrm{V}$, et al. FIB-4: an inexpensive and accurate marker of fibrosis in HCV infection. Comparison with liver biopsy and fibrotest. Hepa- tology 2007;46:32-36.

43. Wai CT, Greenson JK, Fontana RJ, Kalbfleisch JD, Marrero JA, Conjeevaram $\mathrm{HS}$, et al. A simple noninvasive index can predict both significant fibrosis and cirrhosis in patients with chronic hepatitis C. Hepatology 2003;38:518-526.

44. Castéra L, Vergniol J, Foucher J, Le Bail B, Chanteloup E, Haaser M, et al. Prospective comparison of transient elastography, Fibrotest, APRI, and liver biopsy for the assessment of fibrosis in chronic hepatitis C. Gastroenterology 2005;128:343-350.

45. Afdhal NH, Bacon BR, Patel K, Lawitz EJ, Gordon SC, Nelson DR, et al. Accuracy of fibroscan, compared with histology, in analysis of liver fibrosis in patients with hepatitis B or C: a United States multicenter study. Clin Gastroenterol Hepatol 2015;13:772-779.e3.

46. Toyoda H, Kumada T, Tada T, Kiriyama S, Tanikawa M, Hisanaga Y, et al. Risk factors of hepatocellular carcinoma development in noncirrhotic patients with sustained virologic response for chronic hepatitis C virus infection. J Gastroenterol Hepatol 2015;30:1183-1189.

47. Akuta N, Kobayashi M, Suzuki F, Sezaki H, Fujiyama S, Kawamura Y, et al. Liver fibrosis and body mass index predict hepatocarcinogenesis following eradication of hepatitis C virus RNA by direct-acting antivirals. Oncology 2016;91:341-347.

48. Kobayashi M, Suzuki F, Fujiyama S, Kawamura Y, Sezaki H, Hosaka T, et al. Sustained virologic response by direct antiviral agents reduces the incidence of hepatocellular carcinoma in patients with HCV infection. J Med Virol 2017;89:476-483.

49. Lee K, Sinn DH, Gwak GY, Cho HC, Jung SH, Paik YH, et al. Prediction of the risk of hepatocellular carcinoma in chronic hepatitis $C$ patients after sustained virological response by aspartate aminotransferase to platelet ratio index. Gut Liver 2016;10:796-802.

50. Yu ML, Lin SM, Lee CM, Dai CY, Chang WY, Chen SC, et al. A simple noninvasive index for predicting long-term outcome of chronic hepatitis C after interferon-based therapy. Hepatology 2006;44:10861097.

51. Jung KS, Kim SU, Ahn SH, Park YN, Kim DY, Park JY, et al. Risk assessment of hepatitis B virus-related hepatocellular carcinoma development using liver stiffness measurement (FibroScan). Hepatology 2011;53:885-894.

52. Masuzaki R, Tateishi R, Yoshida H, Yoshida H, Sato S, Kato N, et al. Risk assessment of hepatocellular carcinoma in chronic hepatitis C patients by transient elastography. J Clin Gastroenterol 2008;42:839-843.

53. Wang JH, Yen $\mathrm{YH}$, Yao CC, Hung $\mathrm{CH}$, Chen $\mathrm{CH}$, Hu TH, et al. Liver stiffness-based score in hepatoma risk assessment for chronic hepatitis C patients after successful antiviral therapy. Liver Int 2016:36:1793-1799.

54. Lee HW, Chon YE, Kim SU, Kim BK, Park JY, Kim DY, et al. Predicting liver-related events using transient elastography in chronic hepatitis C patients with sustained virological response. Gut Liver 
2016;10:429-436.

55. Tachi Y, Hirai T, Toyoda H, Tada T, Hayashi K, Honda T, et al. Predictive ability of laboratory indices for liver fibrosis in patients with chronic hepatitis $C$ after the eradication of hepatitis $C$ virus. PLoS One 2015;10:e0133515.

56. D'Ambrosio R, Degasperi E, Aghemo A, Fraquelli M, Lampertico P, Rumi $M G$, et al. Serological tests do not predict residual fibrosis in hepatitis C cirrhotics with a sustained virological response to interferon. PLoS One 2016;11:e0155967.

57. Sherman M. Surveillance for hepatocellular carcinoma. Best Pract Res Clin Gastroenterol 2014;28:783-793.

58. Sarasin FP, Giostra E, Hadengue A. Cost-effectiveness of screening for detection of small hepatocellular carcinoma in western patients with Child-Pugh class A cirrhosis. Am J Med 1996;101:422-434.

59. Nouso K, Tanaka H, Uematsu S, Shiraga K, Okamoto R, Onishi H, et al. Cost-effectiveness of the surveillance program of hepatocellular carcinoma depends on the medical circumstances. J Gastroenterol Hepatol 2008;23:437-444.

60. Lin OS, Keeffe EB, Sanders GD, Owens DK. Cost-effectiveness of screening for hepatocellular carcinoma in patients with cirrhosis due to chronic hepatitis C. Aliment Pharmacol Ther 2004;19:1159-1172.

61. Marrero JA, Kulik LM, Sirlin CB, Zhu AX, Finn RS, Abecassis MM, et al. Diagnosis, staging, and management of hepatocellular carcinoma: 2018 practice guidance by the American Association for the Study of Liver Diseases. Hepatology 2018;68:723-750.

62. Korean Association for the Study of the Liver. KASL clinical practice guidelines: management of hepatitis C. Clin Mol Hepatol 2016;22:76-139.

63. Omata M, Kanda T, Wei L, Yu ML, Chuang WL, Ibrahim A, et al. APASL consensus statements and recommendations for hepatitis C prevention, epidemiology, and laboratory testing. Hepatol Int 2016;10:681-701. 